\title{
Influence of Chronic Renal Failure on Protein Synthesis and Albumin Metabolism in Rat Liver
}

\author{
Stanley B. Grossman, S. H. Yap, and David A. Shafritz \\ From the Departments of Medicine and Cell Biology, and the Liver Research Center, Albert \\ Einstein College of Medicine, Bronx, New York 10461
}

\begin{abstract}
A B S T R A C T Chronic renal failure in rats leads to changes in hepatic protein synthesis and albumin metabolism at both the cellular and molecular level. In rats with chronic uremia (blood urea nitrogen $>45 \mathrm{mg} / 100 \mathrm{ml} 1 \mathrm{mo}$ after surgical reduction in renal mass), cell-free protein synthesis is reduced $30-40 \%$ in liver membrane-bound polyribosomes. Albumin synthesis by membrane-bound polysomes in uremia is reduced even more than the reduction in total protein synthesis. Activity of free polysomes remains normal. There is also intracellular accumulation of albumin in liver of uremic rats and a concomitant decrease in serum albumin. In normal liver, most intracellular albumin is located in the microsomal fraction, whereas in liver from uremic animals the excess albumin is found in the free cytosol fraction. These results can be explained either by a defect in synthesis of albumin by membrane-bound polysomes with release of newly synthesized albumin into the cytosol or by a reduced ability of polysomes synthesizing albumin to associate with the membrane fraction in rats with chronic renal failure.
\end{abstract}

\section{INTRODUCTION}

Under normal circumstances, the kidney exerts little influence on synthesis (1) or degradation of albumin (2). In various forms of renal disease, the metabolism of albumin and other serum proteins is changed considerably (3-5). In nephrotic syndrome, there is increased albumin degradation $(6,7)$, as well as loss of albumin through the glomerulus. Although decreased serum albumin levels are found consistently in such patients, both increased $(8,9)$ and normal albumin synthetic rates $(10-12)$ have been reported. In contrast, in vitro studies of nephrotic syndrome in rats have reported an increase in albumin synthesis (13-16). Amino acid incorporation and cellular

Received for publication 7 October 1976 and in revised form 10 December 1976.
protein/DNA ratios have also been reported to be increased in liver of uremic or nephrectomized rats $(17,18)$. However, in patients with chronic uremia, increased albumin catabolism with concomitant reduction in serum albumin does not lead to a compensatory increase in albumin synthesis (19). Other studies have indicated that albumin synthesis is decreased in patients with chronic renal failure and that hemodialysis improves both serum albumin levels and albumin synthetic rates (5). Improvement of albumin metabolism in these patients was thought to result indirectly from improved nutrition, rather than a change in hepatic protein synthesis activity upon correction of uremia. Therefore, in man and experimental animals, alterations in albumin synthesis rates have been observed in renal failure, but it is unclear whether the uremic syndrome directly influences the ability of the liver to synthesize this important serum protein.

Recently, Black et al. ${ }^{1}$ reported structural and functional changes in the hepatic endoplasmic reticulum $(\mathrm{ER})^{2}$ of rats with chronic renal failure produced by surgical reduction in renal mass. These changes included decreased activity of certain microsomal drug metabolizing enzymes, vesiculation and disorganization of the ER, and degranulation of membrane-bound polyribosomes. The present studies were designed to determine the effects of chronic renal failure on albumin synthesis and metabolism at both the cellular and molecular level. We have found that synthesis of albumin and total liver protein is depressed specifically in liver membrane-bound polysomes of uremic animals. In addition, there is a concomitant increase in hepatic intracellular albumin, located specifically

${ }^{1}$ Black, M., L. Biempica, S. Goldfischer, I. M. Arias, and S. Grossman. 1977. Effect of chronic renal failure in rats on structure and function of the hepatic endoplasmic reticulum. Exp. Mol. Pathol. In press.

${ }_{2}^{2}$ Abbreviations used in this paper: BUN, blood urea nitrogen; ER, endoplasmic reticulum. 
within the free cytosol fraction. These results can be explained by a model recently proposed for synthesis of all secretory proteins in eukaryotic cells (20) and suggest further that in the uremic state, there is decreased formation of active complexes between albumin-synthesizing polysomes and ER membranes.

\section{METHODS}

Preparation of animals. Male Sprague-Dawley rats weighing 190-230 $\mathrm{g}$ were rendered azotemic by right nephrectomy and segmental infarction of the left kidney (21). After surgery, rats were given standard Purina chow diet (Ralston Purina Co., St. Louis, Mo.) and water ad lib. $\mathrm{NaCl}(0.9 \%)$ was added to the drinking water from the 4th postoperative day to avoid sodium deficiency. For some studies, control rats and rats with chronic renal failure were pair-fed with a nutritionally balanced liquid diet prepared by the formula of Lieber et al. (22). This diet was obtained commercially from Bio-Serv., Inc., Frenchtown, N. J. 3 wk after surgery, $1 \mathrm{ml}$ of blood was obtained by cardiac puncture for determination of blood urea nitrogen (BUN). Only those rats with BUN levels $>45 \mathrm{mg} / 100 \mathrm{ml}$ were considered uremic and were used in experimental studies. 1 wk later, control and uremic animals were decapitated and blood was collected for determination of final BUN and serum albumin levels.

Separation of membrane-bound and free liver polysomes. The liver was removed rapidly, weighed, and perfused with $60 \mathrm{ml}$ of cold rinse solution $(10 \mathrm{mM}$ Tris- $\mathrm{HCl}, \mathrm{pH} 7.4-150$ $\mathrm{mM} \mathrm{NaCl}-150 \mu \mathrm{g} / \mathrm{ml}$ heparin), followed by $60 \mathrm{ml}$ of homogenizing buffer (250 mM sucrose, $20 \mathrm{mM}$ Tris- $\mathrm{HCl}, \mathrm{pH} \mathrm{7.4}$, $25 \mathrm{mM} \mathrm{KCl,} 2 \mathrm{mM} \mathrm{MgCl}, 2 \mathrm{mM}$ dithiothreitol, $0.1 \mathrm{mM}$ EDTA, $150 \mu \mathrm{g} / \mathrm{ml}$ heparin). Subsequent procedures were performed at $4^{\circ} \mathrm{C}$. $2 \mathrm{vol}$ of homogenizing buffer was added to pooled liver from control or uremic animals, and livers were minced and homogenized with three strokes of a loosefitting Dounce homogenizer (Kontes Co., Vineland, N. J.). More thorough homogenization was obtained with a motordriven, glass-teflon conical Potter-Elvehjem homogenizer (Potter Instrument Co., Inc., Plainview, N. Y.). Liver homogenates were centrifuged sequentially at $480 \mathrm{~g}$ for 2 $\mathrm{min}, 1,935 \mathrm{~g}$ for $2 \mathrm{~min}, 7,710 \mathrm{~g}$ for $5 \mathrm{~min}$, and $17,300 \mathrm{~g}$ for 10 min in a Sorvall RC-5 centrifuge (Ivan Sorvall, Inc., Norwalk, Conn.).

Membrane-bound and free polysomes were isolated from the $17,300 \mathrm{~g}$ supernatant fraction by discontinuous sucrose gradient centrifugation as previously described (23). A multilayer gradient system was used. Each gradient layer contained $1 / 5$ vol of crude rat liver $105,000 \mathrm{~g}$ supernatant protein, isolated from a previous preparation of liver cellfree components. The bottom layer of the gradient $(6.5 \mathrm{ml})$ contained $1.8 \mathrm{M}$ sucrose (Schwarz-Mann Ultra Pure, ribonuclease-free; Schwarz-Mann, Div. Becton, Dickinson \& Co., Orangeburg, N. Y.) in $20 \mathrm{mM}$ Tris-HCl (pH 7.4), 25 $\mathrm{mM} \mathrm{KCl}, 2 \mathrm{mM} \mathrm{MgCl}_{2} ; 2 \mathrm{mM}$ dithiothreitol, $0.1 \mathrm{mM}$ EDTA, the middle layer $(7.5 \mathrm{ml})$ contained $1.45 \mathrm{M}$ sucrose in the same solution, and the top layer $(\sim 16 \mathrm{ml})$ contained postmitochondrial supernate in the original $0.25 \mathrm{M}$ sucrose homogenizing solution. Centrifugation was performed in a Beckman model 30 rotor (Beckman Instruments, Inc., Cedar Grove, N. J.) at $78,000 \mathrm{~g}$ av for a minimum of $16 \mathrm{~h}$. Free and membrane-bound polysomes were harvested and stored in small portions in liquid nitrogen (23).

Polymerization assays. For determination of protein synthesis activity in the cell-free system, incubations were per- formed at $30^{\circ} \mathrm{C}$ in a $50-\mu \mathrm{l}$ vol for $10 \mathrm{~min}$ (membrane-bound polysomes) or for $20 \mathrm{~min}$ (free polysomes). These incubation times were optimal for amino acid incorporation during the period in which protein synthesis is still increasing. Reaction mixtures contained $15 \mathrm{mM}$ Tris- $\mathrm{HCl}$ ( $\mathrm{pH}$ 7.5), $4 \mathrm{mM} \mathrm{MgCl}, 80 \mathrm{mM} \mathrm{KCl}, 1 \mathrm{mM}$ ATP, $0.2 \mathrm{mM}$ GTP, 3 $\mathrm{mM}$ PEP, 0.2 IU of pyruvate kinase (rabbit muscle), 1 $\mathrm{mM}$ dithiothreitol, $0.08 \times 10^{-3} \mathrm{M}$ mixture of 19 unlabeled amino acids minus leucine, 0.10-1.0 $\mathrm{A}_{260}$ units of free polysomes or 0.10-0.80 $\mathrm{A}_{260}$ units of membrane-bound polysomes, $0.67 \mathrm{mg}$ of $105,000 \mathrm{~g}$ rat liver supernatant protein, $0.06 \mathrm{~A}_{280}$ units of deacylated rabbit liver tRNA, and L$\left[{ }^{14} \mathrm{C}\right]$ leucine (sp act $324 \mathrm{mCi} / \mathrm{mmol}$ ). To determine the optimal incubation conditions for $\left[{ }^{14} \mathrm{C}\right]$ leucine incorporation with liver polysomes from control and uremic animals, assays were performed with several concentrations of polysomes, liver supernatant protein, $\mathrm{MgCl}_{2}$, and $\mathrm{KCl}$. In certain experiments, liver supernatant protein from uremic animals was tested for its influence on amino acid incorporation. Incorporation of $\left[{ }^{14} \mathrm{C}\right]-$ or $\left[{ }^{3} \mathrm{H}\right]$ leucine into protein was measured as labeled polypeptide which was insoluble in $10 \%$ TCA after heating to $95^{\circ} \mathrm{C}$ for $20 \mathrm{~min}(24)$.

Isolation of rat serum albumin and preparation of $\left[{ }^{14} \mathrm{C}\right.$ ]albumin. Adult $(300 \mathrm{~g})$ male Sprague-Dawley rats were decapitated. Their blood was collected, allowed to clot, and centrifuged at $7,700 \mathrm{~g}$ for $15 \mathrm{~min}$, followed by recentrifugation of the serum at $17,300 \mathrm{~g}$ for $10 \mathrm{~min}$. Ammonium sulfate was added to $50 \%$ saturation, and precipitated protein was removed by centrifugation. Additional ammonium sulfate was added to the supernatant fraction to a final concentration of $90 \%$ saturation. Precipitated protein was collected by centrifugation, dissolved in $0.1 \mathrm{M}$ Tris- $\mathrm{HCl}$, pH 7.8, and dialyzed against the same buffer. Dialyzed protein was placed over a $1.5 \times 25$-cm column of Whatman (Whatman, Inc., Clinton, N. J.) microgranular DEAE cellulose (DE-52) equilibrated with $0.1 \mathrm{M}$ Tris- $\mathrm{HCl}$ (pH 7.8) and albumin was eluted with a $0.1 \mathrm{M}-0.3 \mathrm{M}$ Tris- $\mathrm{HCl}$, pH 7.8, linear gradient. Fractions containing albumin (as determined by optical density readings at $280 \mathrm{~nm}$ ) were pooled and rechromatographed on a second DEAE cellulose column. The peak tubes were pooled and concentrated to a volume of $0.3 \mathrm{ml}$ by ultrafiltration, using an Amicon UM-10 membrane filter (Amicon Corp., Lexington, Mass.). This material was placed over a precalibrated $1.0 \times 60-\mathrm{cm}$ column of Sephadex G-100 equilibrated with $10 \mathrm{mM} \mathrm{NaPO}$ (pH 7.4), $150 \mathrm{mM} \mathrm{NaCl}$, and $1 \mathrm{mM}$ dithiothreitol. Elution was performed with the same buffer at a flow rate of 1.0$2.0 \mathrm{ml} / \mathrm{h}$, collecting $0.5 \mathrm{ml}$ fractions. The elution pattern was determined by monitoring absorbance at $280 \mathrm{~nm}$. Material in the peak tube from the Sephadex G-100 column was used for preparation of $\left[{ }^{14} \mathrm{C}\right]$ albumin. Purified albumin was labeled chemically with ${ }^{14} \mathrm{C}$ formate by reductive methylation as described by Crane and Miller (25).

Isolation of antibody fractions. $\gamma$ globulin from nonimmune rabbit serum was purified by the method of Palacios et al. (26) and was used for preparation of goat antirabbit $\gamma$-globulin. New Zealand white rabbits were bled and the serum diluted with an equal volume of $10 \mathrm{mM}$ $\mathrm{NaPO}_{4}$ (pH 7.5), $15 \mathrm{mM} \mathrm{NaCl}$. Neutralized ammonium sulfate was added to a final saturation of $40 \%$. A precipitate was allowed to form at room temperature for $10 \mathrm{~min}$ and was centrifuged at $12,000 \mathrm{~g}$ for $20 \mathrm{~min}$. The pellet was dissolved in $100 \mathrm{ml}$ of the above buffer and a second 0$40 \%$ ammonium sulfate precipitation performed. The pellet was dissolved in $1 / 2$ the original serum volume with 10 $\mathrm{mM} \mathrm{NaPO}$ ( $\mathrm{pH}^{7.2}$ ), $15 \mathrm{mM} \mathrm{NaCl}$ and dialyzed against the same buffer. The dialyzed material was clarified by centrifugation at $7,700 \mathrm{~g}$ for $15 \mathrm{~min}$ and applied to a column 
$2 \mathrm{~cm}$ in diameter containing a $5-\mathrm{cm}$ height of Whatman DEAE-52 cellulose overlaid with 5 -cm Whatman microgranular carboxymethyl cellulose (CM-52) in $10 \mathrm{mM} \mathrm{NaPO}$ (pH 7.2), $15 \mathrm{mM} \mathrm{NaCl}$ (26). The column was run at a flow rate of $12 \mathrm{ml} / \mathrm{h}$, collecting $5-\mathrm{ml}$ fractions. Elution was monitored by UV absorbance at $280 \mathrm{~nm}$ and showed a single peak of $\gamma$-globulin protein. This material was dialyzed against $1 \mathrm{mM}$ EDTA ( $\mathrm{pH}$ 7.4) and used as antigen for immunization of goats.

Goat antiserum to purified rabbit $\gamma$-globulin was produced by a series of three semiweekly subcutaneous injections of purified antigen in complete Freund's adjuvant for the first injection and in incomplete Freund's adjuvant for subsequent injections. This material was purified through the ammonium sulfate step indicated above and was used for indirect immunoprecipitation. Rabbit anti-rat albumin antibody was obtained commercially from ICN Pharmaceuticals, Inc. (Cleveland, Ohio), and was judged monospecific by immunodiffusion, immunoelectrophoresis, and Kabat precipitation analysis (27). Rabbit antiserum to ricin, a plant protein, was obtained from Dr. Margolis and Dr. Scharff of the Albert Einstein College of Medicine and was utilized for nonspecific or "clearing" immunoprecipitation of ${ }^{3} \mathrm{H}$-labeled cell-free reaction products.

Immunological analysis of cell-free reaction products. Determination of $\left[{ }^{3} \mathrm{H}\right]$ albumin in the cell-free protein synthesis reaction product was performed by indirect immunoprecipitation. For these studies, $0.5-1.0 \mathrm{ml}$ incubations were performed with proportionate increases in reaction components and $\left[{ }^{3} \mathrm{H}\right]$ leucine (sp act $10 \mathrm{Ci} / \mathrm{mmol}$ ) in substitution for $\left[{ }^{14} \mathrm{C}\right] l$ leucine. After protein synthesis was completed, $30 \mu \mathrm{l}$ of $0.05 \mathrm{M}\left[{ }^{12} \mathrm{C}\right]$ leucine was added, and incorporation of radioactivity into hot TCA-insoluble polypeptides determined on a $10-\mu \mathrm{l}$ aliquot. The reaction mixture was placed on ice and $\left[{ }^{14} \mathrm{C}\right]$ albumin carrier $(0.8 \mu \mathrm{g}, 3,125 \mathrm{cpm} / \mu \mathrm{g})$ added. $5 \% \mathrm{Na}$ deoxycholate was added to a final concentration of $0.5 \%$, and the reaction mixture dialyzed against $13 \mathrm{mM} \mathrm{NaHCO}, 150 \mathrm{mM} \mathrm{NaCl}$, and $5 \mathrm{mM} \beta$-mercaptoethanol, followed by a second dialysis against $10 \mathrm{mM} \mathrm{NaPO}_{4}$ $(\mathrm{pH} 7.4), 150 \mathrm{mM} \mathrm{NaCl}$, and $5 \mathrm{mM} \beta$-mercaptoethanol. The dialyzed material was clarified by centrifugation in a Brinkman microcentrifuge $(8,000 \mathrm{~g}$ for $20 \mathrm{~min}$; Brinkman Instruments, Inc., Westbury, N. Y). To the aqueous fraction, $4 \mathrm{M}$ urea was added to a final concentration of $1 \mathrm{M}$ and $10 \%$ Triton X-100 to a final concentration of $1 \%$, followed by rabbit antiricin serum. The reaction was incubated at $30^{\circ} \mathrm{C}$ for $1 \mathrm{~h}$, followed by addition of goat antirabbit $\gamma$-globulin and incubation for an additional $30 \mathrm{~min}$. The reaction mixture was transferred to ice and immunoprecipitation continued for $4 \mathrm{~h}$. Immunoprecipitates were collected by centrifugation in the Brinkman microcentrifuge, resuspended in $1 \%$ Triton $\mathrm{X}-100,10 \mathrm{mM} \mathrm{NaPO}{ }_{4}(\mathrm{pH} \mathrm{7.4)}$, $150 \mathrm{mM} \mathrm{NaCl}, 1 \mathrm{mM}\left[{ }^{12} \mathrm{C}\right]$ leucine, and recentrifuged. The precipitate was dissolved in $0.2 \mathrm{ml}$ of $5 \mathrm{~N} \mathrm{NaOH}$, diluted to $2 \mathrm{ml}$ with $10 \% \mathrm{TCA}$, and heated at $90^{\circ} \mathrm{C}$ for $20 \mathrm{~min}$. The material was cooled on ice for $10 \mathrm{~min}$ to reprecipitate protein, and the precipitate was collected on a nitrocellulose filter. The filter was washed four times with a total of 20 $\mathrm{ml}$ of 5\% TCA and counted by liquid scintillation spectroscopy in $10 \mathrm{ml}$ of Bray's solution (New England Nuclear, Boston, Mass.). Antiricin- $\gamma$-globulin precipitation was considered "nonspecific" and was repeated until immunoprecipitated ${ }^{3} \mathrm{H}$-radioactivity was reduced below $300 \mathrm{cpm}$ (generally 2 or 3 steps). No $\left[{ }^{14} \mathrm{C}\right]$ albumin carrier was precipitated during these procedures. Specific rabbit antirat albumin antibody was then added and indirect immunoprecipitation repeated. Both $\left[{ }^{14} \mathrm{C}\right]$ albumin tracer and $\left[{ }^{3} \mathrm{H}\right]$ "albuminlike" cell-free product were precipitated during this step, and efficiency of albumin immunoprecipitation was determined by computing the percentage of added $\left[{ }^{14} \mathrm{C}\right]$ albumin recovered. Double isotope counting procedures, by using the method of internal standardization, were utilized for estimating ${ }^{14} \mathrm{C}$ and ${ }^{3} \mathrm{H}$ in the immunoprecipitates.

Determination of intracellular albumin levels. Equal volumes of homogenate from perfused livers of control and uremic rats were centrifuged in a Sorvall RC-5 refrigerated centrifuge at $480 \mathrm{~g}$ for $2 \mathrm{~min}$. The nuclear pellet was washed four times with $5 \mathrm{ml}$ of homogenizing buffer, and the wash fractions combined with the initial postnuclear supernate. A microsomal fraction and $105,000 \mathrm{~g}$ supernatant protein were prepared, and total albumin determined in these fractions as described below. $5 \% \mathrm{Na}$ deoxycholate was added to the supernate and resuspended microsomes to a final concentration of $0.5 \%$. $\left[{ }^{14} \mathrm{C}\right]$ Albumin $(25,000$ cpm) was added to all fractions as a carrier for repurification and for estimating recovery of intracellular albumin. The materials were dialyzed against two changes of $100 \mathrm{mM}$ Tris- $\mathrm{HCl}(\mathrm{pH} 7.8)$ and purified through DEAE cellulose and Sephadex G-100 as described above. The final material was electrophoresed on a $6.5 \%$ sodium dodecyl sulfate (SDS) polyacrylamide gel, stained with Coomassie Blue, and scanned by absorbance at $540 \mathrm{mM}$ on a Gilford recording spectrometer (Gilford Instrument Laboratories Inc., Oberlin, Ohio). Albumin was quantitated by determining the proportion of Coomassie Blue staining material under the albumin peak in comparison to albumin standards. In the various fractions in which albumin was repurified, approximately $80 \%$ of the protein migrated to the position of albumin standard. Total protein in these samples was determined by the method of Lowry et al. (28).

To determine contamination of liver subcellular fractions with serum albumin, ${ }^{125}$ I-labeled albumin was injected i.v. into control and uremic male Sprague-Dawley rats. After $10 \mathrm{~min}$ the rats were decapitated, the serum collected, and the liver processed as above. In liver that had been perfused before homogenization, less than $10 \%$ of recovered albumin resulted from serum contamination. In nonperfused liver, cross-contamination accounted for more than $50 \%$ of recovered albumin.

\section{RESULTS}

For all studies, Sprague-Dawley rats were littermates and were divided into two groups, control and experimental (uremic). The general appearance of experimental animals was comparable to the control group. Except for the first three postoperative days, rats with chronic renal failure (uremic) gained weight in parallel fashion to control animals and generally achieved full weight of controls by the end of 1 mo (Fig. 1). In pair-fed animals, weight gain was identical in control and uremic groups. Occasional rats with chronic renal failure were sluggish, ate poorly, and did not gain weight at the expected rate. These animals were excluded from the present study. The mean BUN level in uremic rats was $62 \pm$ SEM $2.7 \mathrm{mg} / 100 \mathrm{ml}$ compared to $24 \pm \mathrm{SEM} 0.9 \mathrm{mg} / 100 \mathrm{ml}$ in control animals $(P<0.001$; Table I). The mean serum albumin was reduced from a control value of $3.23 \pm$ SEM 0.09 $\mathrm{g} / 100 \mathrm{ml}$ to $2.82 \pm \mathrm{SEM} 0.08 \mathrm{~g} / 100 \mathrm{ml}$ in uremic rats $(P<0.001)$. Studies with ${ }^{125}$ I-labeled albumin showed 


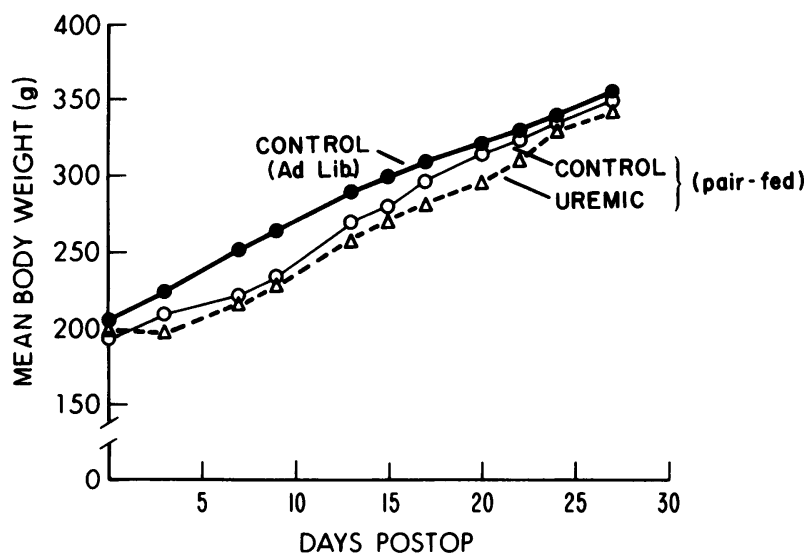

Figure 1 Weight gain in control vs. uremic rats. Animals were littermates and were housed separately in paired cages. Chronic renal failure (uremia) was produced surgically in one animal from each pair. In the pair-feeding experiment, control rats were given the amount of food in liquid suspension that their uremic littermates had eaten the previous day. Each point represents the mean body weight for nine animals, and there was no statistical difference in the various groups.

no significant change in plasma volume in uremic animals. To determine whether the intracellular level of albumin was affected by chronic renal failure, control and uremic animals were sacrificed; the livers were removed, perfused, and homogenized as noted in Methods. There was no difference in appearance or weight of the liver in uremic animals. Albumin was recovered and purified from the liver homogenates. In normal rats, the amount of albumin in the microsomal fraction was higher than that found in the cytosol fraction (Table II). In uremic animals, the amount of albumin in the microsomal fraction was unchanged from control, but albumin in the cytosol fraction was increased twofold. The concentration of albumin in the cytosol of uremic animals was actually higher than that found in the microsomal fraction (Table II). Together with the reduction in serum albumin, these results suggest a significant abnormality in liver albumin metabolism in rats with chronic renal failure.

TABLE I

BUN and Serum Albumin Levels in Control and Uremic Rats

\begin{tabular}{lcc}
\hline Group of rats & BUN & Serum albumin \\
\hline & $m g / 100 \mathrm{ml}$ & $\mathrm{g} / 100 \mathrm{ml}$ \\
Control & $24 \pm$ SEM 0.9(15)* & $3.23 \pm$ SEM 0.09(15) \\
Uremic & $62 \pm$ SEM 2.7(28) & $2.82 \pm$ SEM 0.07(28) \\
& $P<0.001$ & $P<0.001$ \\
\hline
\end{tabular}

* Numbers in parentheses refer to the number of animals in each group.
To study the influence of chronic renal failure on hepatic protein synthesis at the subcellular level, liver membrane-bound and free polysomes were prepared simultaneously from control and uremic animals. Sucrose gradient analysis revealed a decrease in the average size of polysomes in uremic animals (Fig. 2 A, B). This effect was more dramatic in membrane-bound polysomes of uremic animals and was associated with an increased percentage of dimers, monomers, and ribosomal subunits as compared to control membrane-bound ribosomes (Fig. 2 B). These results are consistent with earlier electronmicroscope findings of degranulation of the rough ER in liver of uremic animals. ${ }^{1}$

Experiments were performed to determine whether cell-free incorporation of amino acids into protein was affected in rats with chronic renal failure. The assay for protein synthesis was standardized for maximal incorporation, using polysomes and $105,000 \mathrm{~g}$ supernatant protein from control and uremic rat liver. As shown in Fig. 3, incorporation of $\left[{ }^{14} \mathrm{C}\right]$ leucine into protein was linear for $20 \mathrm{~min}$ with free polysomes (Fig. $3 \mathrm{~A}$ ), and there was essentially no difference between control and uremic animals. With membrane-bound polysomes, the increase with time was not linear (Fig. $3 \mathrm{~B}$ ), but at all time-points there was $30-40 \%$ less activity with membrane-bound polysomes from uremic compared to control animals. At various levels of polysomal RNA in the assay, there was no difference in amino acid incorporation with free polysomes from uremic versus control animals (Fig. 4 A). With membrane-bound polysomes from uremic versus control rats, amino acid incorporation was reduced $\sim 30 \%$ at all levels of polysomal RNA tested (Fig. 4 B). For a given preparation of membranebound and free polysomes from control versus uremic animals, these results were highly reproducible. Although there was some variation in the specific activity of polysomes from preparation to preparation (i.e., cpm $\left[{ }^{3} \mathrm{H}\right]$ leucine incorporated into protein $/ \mu \mathrm{g}$ polysomal RNA), the percentage reduction in protein synthesis activity was constant for each preparation compared to its own control. The above results were

TABLE II

Intracellular Albumin Levels in Liver of Control and Uremic Rats

\begin{tabular}{llc}
\hline Cell fraction & & Albumin/liver \\
\hline \multirow{3}{*}{ Microsomal } & Control & $\mu g / g$ \\
& Uremic & 178 \\
& & 177 \\
Cytosol & Control & 118 \\
& Uremic & 234 \\
\hline
\end{tabular}


A

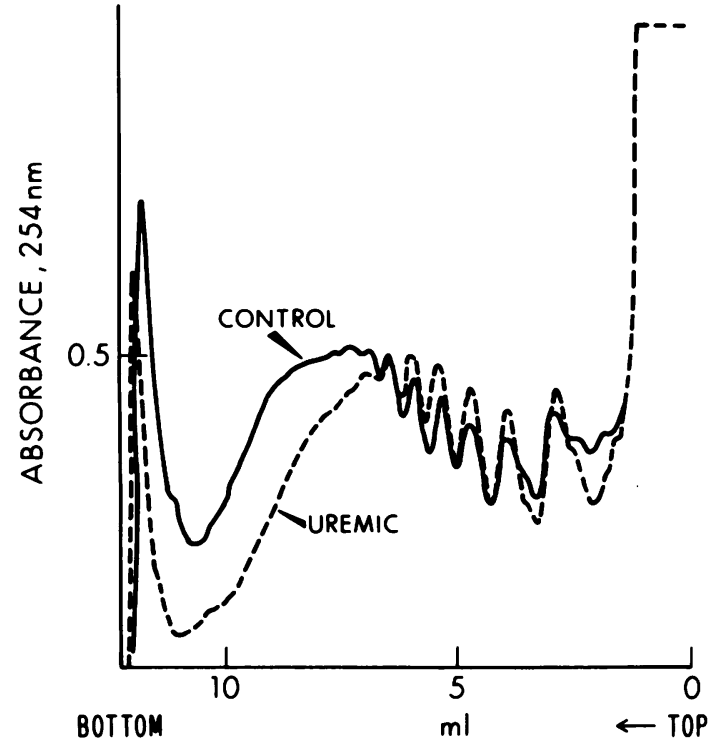

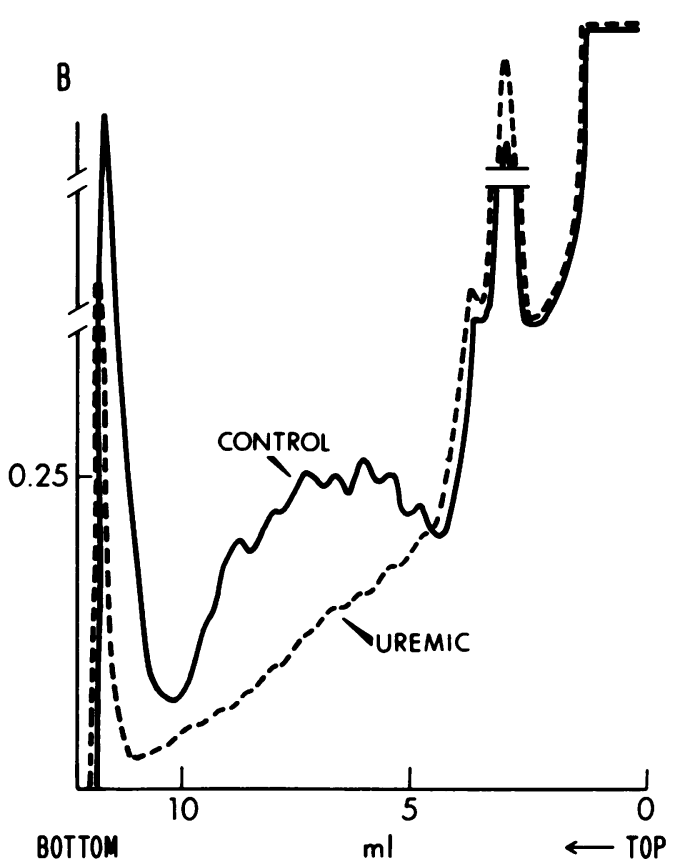

FIGURE 2 Sucrose gradient analysis of rat liver free (A) and membrane-bound (B) polysomes from control and uremic animals. Membrane-bound and free liver polysomes from control and uremic rats were prepared as described in Methods. Free polysomes or membranebound polysomes $\left(2.5 \mathrm{~A}_{280}\right.$ units) were suspended in $0.5 \mathrm{ml}$ buffer $(0.25 \mathrm{M}$ sucrose, $10 \mathrm{mM}$ Tris- $\mathrm{HCl}, \mathrm{pH} 7.4,25 \mathrm{mM} \mathrm{KCl}, 5 \mathrm{mM} \mathrm{MgCl}{ }_{2} 1 \mathrm{mM}$ dithiothreitol, $150 \mu \mathrm{g} / \mathrm{ml} \mathrm{heparin,} \mathrm{and} 1 / 5$ vol rat liver $105,000 \mathrm{~g}$ supernatant protein) and $5 \% \mathrm{Na}$ deoxycholate was added to a final concentration of $0.5 \%$. This material was layered over a $12-\mathrm{ml}, 10-40 \%(\mathrm{wt} / \mathrm{vol})$, exponential sucrose gradient in the same buffer minus supernatant protein. Centrifugation was performed in a Beckman SW 41 rotor at $38,000 \mathrm{rpm}$ for $65 \mathrm{~min}$ at $2^{\circ} \mathrm{C}$. Gradients were withdrawn from the bottom of each tube and absorbance at $254 \mathrm{~nm}$ monitored with an Altex UV monitor model 152 (Altex Scientific Inc., Berkeley, Calif.).

obtained in five of seven preparations. With preparations from pair-fed control vs. uremic rats, there was a $22.4 \%$ reduction in protein synthesis activity with membrane-bound polysomes from uremic animals. With sham-operated rats, protein synthesis activity of both the membrane-bound and free polysome fraction was normal.

To determine whether decreased amino acid incorporation by membrane-bound polysomes in chronic renal failure results from a change in the properties of the polysome, rather than a reduction in activity of enzyme factors or the presence of inhibitors in the liver $105,000 \mathrm{~g}$ supernatant fraction from uremic animals, cross-mixing experiments were performed (Table III). There is little difference in amino acid incorporation, regardless of whether control or uremic supernatant factors are utilized, and membrane-bound polysomes from uremic animals always show less protein synthesis activity than control membranebound polysomes. These results suggest that $105,000 \mathrm{~g}$ liver supernatant factors from uremic animals do not contain a direct toxic inhibitor of protein synthesis. Addition of $600 \mathrm{mg} / 100 \mathrm{ml}$ urea to the cell-free system does not inhibit amino acid incorporation with either membrane-bound or free liver polyribosomes.

To measure synthesis of protein with the immunological properties of albumin in the cell-free system, large scale incubations were performed. Approximately $16 \mathrm{~A}_{260}$ units of membrane-bound polysomes ( $200 \mu \mathrm{g}$ RNA) or $3.8 \mathrm{~A}_{260}$ units of free polysomes $(\sim 100 \mu$ g RNA) were utilized with proportionate increases in other reaction components. $\left[{ }^{3} \mathrm{H}\right]$ Leucine (sp act $10 \mathrm{Ci} / \mathrm{mmol}$ ) was substituted for $\left[{ }^{14} \mathrm{C}\right]$ leucine. As shown in Table IV, the specific activity (cpm incorporated into protein/ $\mu \mathrm{g}$ RNA) of membrane-bound polysomes from uremic animals was reduced compared to controls. In uremic animals the amount of $\left[{ }^{3} \mathrm{H}\right]$ albuminlike material synthesized by membrane-

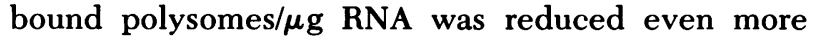
than the reduction in total amino acid incorporation (Table IV). In control liver, the amount of albuminlike material was almost three times greater per $\mu \mathrm{g}$ RNA in membrane-bound polysomes than in free polysomes. However, in liver of animals with uremia, the amount of albuminlike material synthesized by membrane-bound polysomes was reduced to the level 

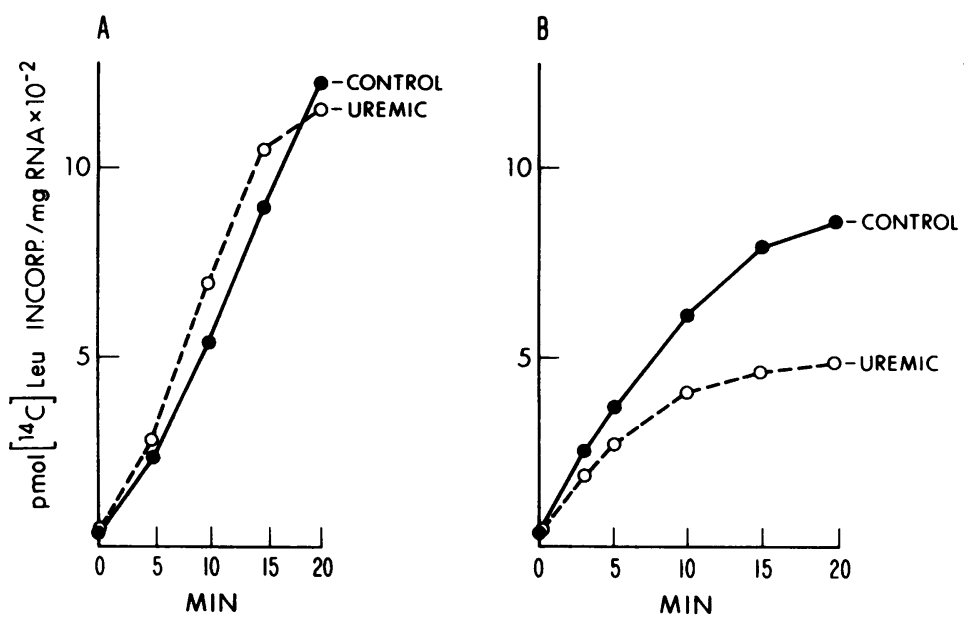

FIgure 3 Time-course for $\left[{ }^{14} \mathrm{C}\right]$ leucine incorporation into protein with rat liver polyribosomes from control and uremic animals. Incubations with free (A) or membrane-bound (B) polysomes were performed at $30^{\circ} \mathrm{C}$ in a volume of $50 \mu \mathrm{l}$ and contained $0.2 \mathrm{~A}_{260}$ units of free polysomes or $0.25 \mathrm{~A}_{260}$ units of membrane-bound polysomes. Incorporation of $\left[{ }^{14} \mathrm{C}\right]$ leucine into protein was determined as radioactive material insoluble in TCA after heating at $90^{\circ} \mathrm{C}$ for 20 min. See Methods for additional experimental details.

produced by free polysomes, which was the same as the activity of control free polysomes. Therefore, inhibition of albumin synthesis was greater than inhibition of overall protein synthesis, and this inhibition occurred specifically in membrane-bound polysomes of uremic animals.

\section{DISCUSSION}

In the present study, we have used an experimental rat model for chronic renal failure and have defined uremia operationally as an elevation of BUN to $>45 \mathrm{mg} / 100 \mathrm{ml}$. Other manifestations comparable to the clinical syndrome of uremia in man are difficult to assess in these animals. Our results suggest that chronic renal failure in rats is associated with decreased synthesis of albumin and other liver proteins. At the same time, there is intracellular accumulation of albumin in the liver, specifically within the free cytosol fraction. Microsomal or intravesicular albumin content appears normal. We have also observed de-
A

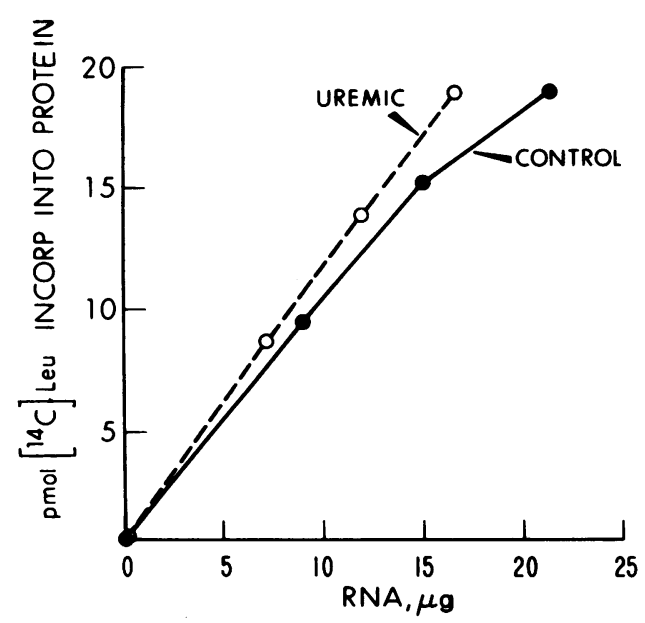

B

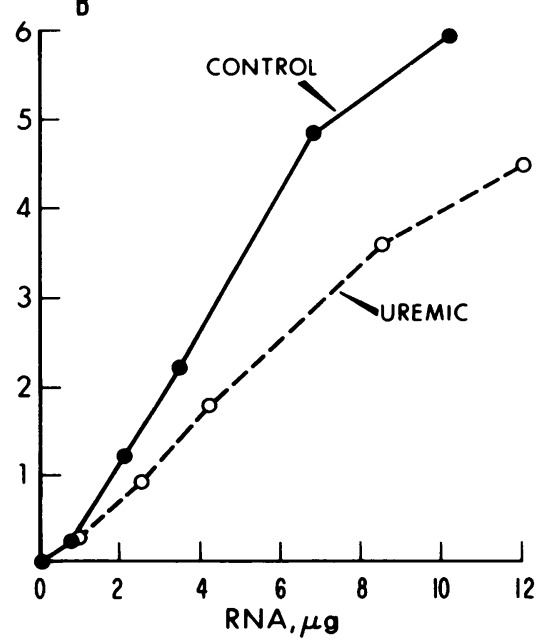

FIGURE 4 Cell-free protein synthesis with polysomes from control and uremic rat liver as a function of polysomal RNA input. Incubations were performed as noted in Fig. 3 with an incubation period of $20 \mathrm{~min}$ for free (A) polysomes and $10 \mathrm{~min}$ for membrane-bound (B) polysomes. Selection of these time-points permitted comparison of protein synthesis activity during the period in which amino acid incorporation was increasing progressively. 
creased protein synthesizing activity of membranebound polyribosomes in the liver of uremic animals and a decrease in the average size of membranebound polysomes in these animals. A decrease in liver protein synthesis activity and average polysome size has been reported in fasting or amino acid deprivation (29-31), acute alcohol administration (32), and carbon tetrachloride toxicity (33). Munro and coworkers $(29,30)$ observed that fasted rats, refed with an amino acid mixture deficient in tryptophan, show an immediate decrease in larger-sized polysomes in liver with a corresponding increase in monosomes and disomes. Sidransky et al. (31) confirmed the effect of tryptophan deficiency in mice and Rothschild et al. (34) and Kelman et al. (35) reported in liver perfusion systems that the depression of albumin synthesis in starved animals is reversed by high doses of tryptophan or a mixture of 11 amino acids. Furthermore, after acute alcohol or carbon tetrachloride administration to liver perfusate, Rothschild et al. $(32,33,36)$ observed that disaggregation of membrane-bound polysomes accompanies the depression of albumin synthesis. These effects are partially ameliorated by the administration of certain amino acids simultaneously with alcohol (36). These observations, together with our present findings in the experimental uremia syndrome, suggest that disaggregation of membranebound polysomes may be a common finding in different pathologic conditions resulting in depression of albumin synthesis.

Other factors that could influence albumin metabolism in the experimental rat model of chronic renal failure include the surgical procedure, amino acid deprivation, or excessive proteinuria. Because only those animals with chronic renal failure which appeared normal and showed normal weight gain at the time of sacrifice were utilized (28-30 days postoperatively), a direct influence of the surgical procedure is doubtful. In addition, studies by other investigators report that factors such as stress, endotoxin injection, or trauma cause an increase rather than a decrease in albumin synthesis (37-39).

Inasmuch as both ad libitum and pair-fed animals gave a normal response in weight gain and showed similar reduction in activity of membrane-bound polysomes, it is unlikely that nutritional factors alone are responsible for the observed phenomena. In patients with chronic renal failure, a low protein diet does not influence albumin synthesis rate (40), and excessive proteinuria increases rather than decreases albumin synthesis $(15,16)$. Therefore, it would appear that the major factor influencing albumin synthesis in this study is a result of chronic renal failure. Whether this effect results from an alteration in the properties of membranes in uremia or is the result of other factors will require further study.
TABLE III

Effect of Supernatant Factors on Endogenous Protein Synthesis in Control and Uremic Rat Liver

\begin{tabular}{lcc}
\hline & \multicolumn{2}{c}{ Supernate } \\
\cline { 2 - 3 } & Control & Uremic \\
\hline & \multicolumn{2}{c}{$\begin{array}{c}\text { pmol [ }{ }^{14} \mathrm{C} \text { ]leucine } \\
\text { incorporated/mg } R N A\end{array}$} \\
Free polysomes & 1,675 & 1,578 \\
Control & 1,699 & 1,311 \\
Uremic & & \\
Membrane-bound polysomes & 762 & 670 \\
Control & 451 & 438 \\
Uremic & \multicolumn{2}{c}{}
\end{tabular}

The decreased synthesis of material identified immunologically as albumin by membrane-bound polysomes was proportionately greater than the decrease in overall protein synthesis. The protein synthetic activity of free cytoplasmic polysomes, however, was normal or slightly increased, and the proportion of albuminlike protein synthesized by free polysomes was unaffected in uremic animals. Previously, we reported that albuminlike material can be synthesized by free cytoplasmic polysomes in rabbit liver (23). However, intact liver membrane-bound polysomes synthesize a higher proportion of complete, fullsized albumin molecules than liver free polysomes (41). In contrast, the relative proportion of albumin that can be translated from total RNA extracted from membrane-bound versus free liver polysomes is similar (41). These results are consistent with a model recently proposed by Blobel and Dobberstein (20) for the synthesis of secretory proteins by eukaryotic cells. According to this model, shown schematically in Fig. 5, all protein synthesis is initiated on free polyribosomes. As protein synthesis proceeds, the $\mathrm{N}$ terminal sequence of the growing nascent chain becomes exposed through the surface of the $60 \mathrm{~S}$ ribo-

\section{TABLE IV}

Synthesis of Albumin-Like Material by Liver Membrane-Bound and Free Polyribosomes from Control Versus Uremic Rats

\begin{tabular}{lcc}
\hline Polysome preparation & $\begin{array}{c}\text { cpm Incorporated } \\
\text { into protein/ } \\
\mu \mathrm{g} \text { RNA }\end{array}$ & $\begin{array}{c}\text { cpm Albumin-like } \\
\text { immunoprecipitate/ } \\
\mu \mathrm{g} \text { RNA }\end{array}$ \\
\hline $\begin{array}{l}\text { Membrane-bound, } \\
\text { Control }\end{array}$ & 3,570 & 135 \\
$\begin{array}{l}\text { Membrane-bound, } \\
\text { Uremic }\end{array}$ & 2,800 & 58 \\
Free, Control & 6,140 & 51 \\
Free, Uremic & 8,220 & 46 \\
\hline
\end{tabular}




\section{Cytosol}

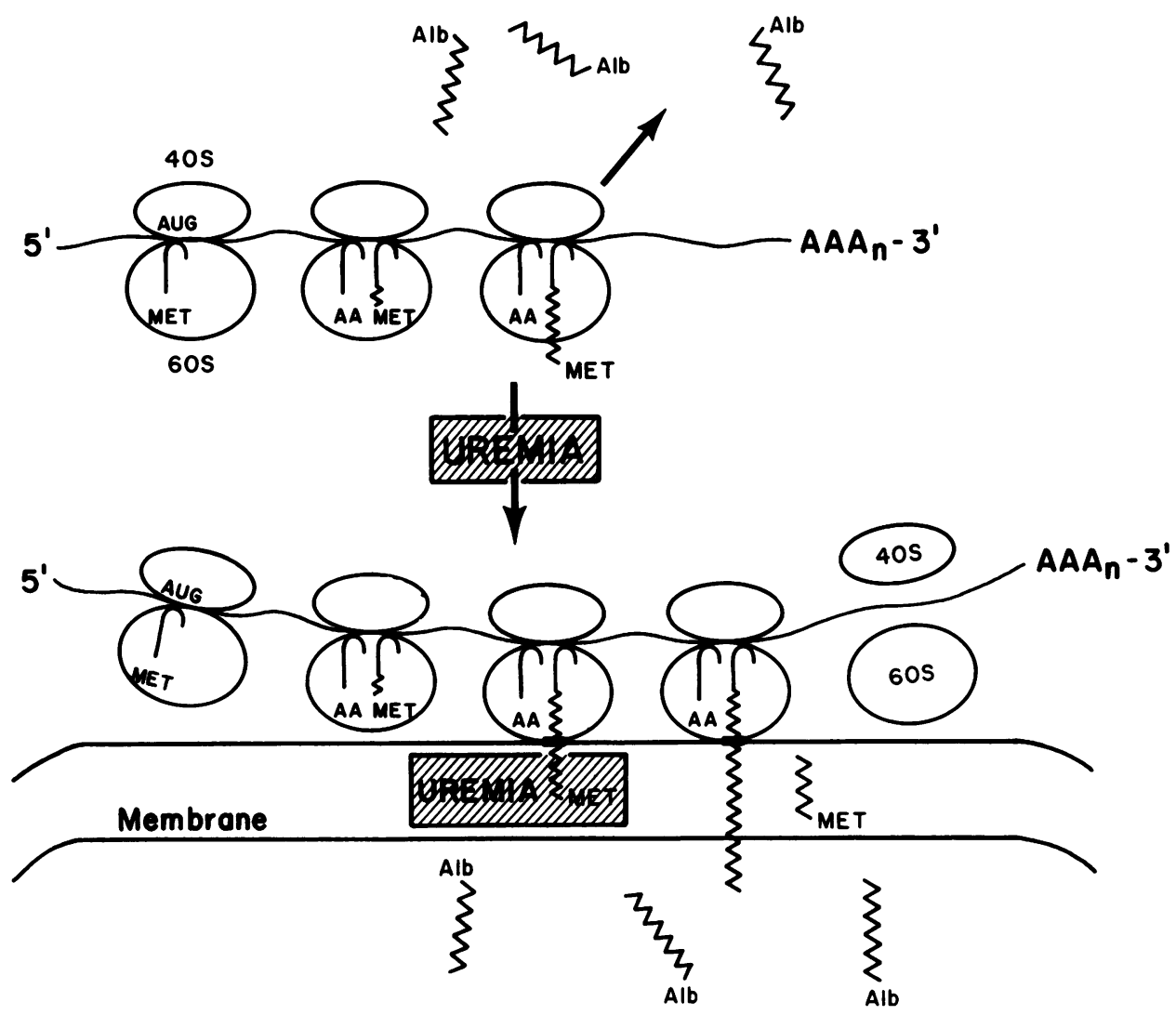

\section{Cisternal Space}

FIGURE 5 Model for synthesis of albumin in liver with proposed derangement(s) in rats with chronic renal failure (uremia).

somal subunit. This sequence is hydrophobic for all secretory proteins and serves as a specific signal for attachment to the membrane of ribosomes synthesizing these proteins. Polypeptide synthesis continues vectorially, and the final product is extruded into the intracisternal space. The $\mathrm{N}$-terminal region, termed the "signal sequence," is cleaved during protein synthesis by an enzyme contained within the membrane and does not appear in the final secreted product. Evidence to support this model has been reported by other investigators $(42,43)$, although many details in the mechanism remain to be established.

This mechanism may explain the intracellular accumulation of albumin in uremic liver cytosol, despite a depression of total albumin synthesis. If initiation of albumin synthesis on free polysomes is normal in rats with uremia, but polysomes bearing albuminnascent chains have reduced ability to enter into the membrane complex (as indicated in Fig. 5), then a significant portion of albumin molecules would be completed on free polysomes and released directly into the cytosol. If albumin cannot be taken up directly by ER membranes, as shown for immunoglobulin light chain protein (44), then accumulation of albumin in the cytosol would occur in uremia, even though the rate of total albumin synthesis is depressed. A block in the albumin secretory pathway would lead to an increase in microsomal or intravesicular albumin. Such observations were not found, although we have not ruled out the possibility that uremic microsomes might be more fragile than normal ER vesicles. Under such circumstances, uremic vesicles might be lysed preferentially during cellular homogenization and their contents released into the free cytosol fraction.

Redman et al. (45) have reported a block in hepatic protein secretion and increased pulse labeling (intracellular accumulation) of albumin in rat liver after colchicine treatment. However, Dorling et al. (46) have not been able to demonstrate changes in hepatic 
albumin steady-state levels in rats after colchicine administration. Baraona et al. (47) have noted increased albumin in liver cytosol of rats maintained on a chronic ethanol diet. These latter investigators conclude that a defect in the microtubular system is responsible for the observed secretory block. The present studies suggest an alternative mechanism for intracellular accumulation of albumin in the liver of rats with chronic renal failure. The basic defect appears to be an inability of polysomes synthesizing secretory proteins to enter into the membrane fraction, and/or a reduced production of albumin by membrane-bound polysomes with release of these molecules into the cytosol fraction. We have not explored why these changes occur in experimental uremia and, indeed, they may not be specific for uremia. By using this approach, however, we should now be able to determine the molecular basis for derangements in hepatic albumin synthesis or metabolism in a wide variety of pathologic conditions, such as cirrhosis of the liver, protein-calorie malnutrition, and alcoholic liver disease.

\section{ACKNOWLEDGMENTS}

The authors thank Dr. Irwin M. Arias for his advice and encouragement during the course of these studies.

This research was supported in part by National Institutes of Health grants AM 17609 and AM 16281, the Irma T. Hirschl Charitable Trust of New York, the Netherlands Organization for Advancement of Pure Research, and Niels Stensen Stiching grants to S. H. Yap, and a National Institutes of Health Research Career Development Award to David A. Shafritz.

\section{REFERENCES}

1. Campbell, P. N., and N. E. Stone. 1957. The synthesis of serum albumin and tissue proteins in slices of rat liver and liver tumor. Biochem. J. 66: 19-31.

2. Katz, J., S. Rosenfeld, and A. L. Sellers. 1960. Role of the kidney in plasma albumin catabolism. Am. J. Physiol. 198: $814-818$.

3. Strober, W., R. P. Mogielnicki, and T. A. Waldmann. 1973. The role of the kidney in the metabolism of serum proteins. Ciba Found. Symp. 9: 25-45.

4. Bianchi, R., G. Fererighi, P. Giagnoni, R. Giordani, R Navalesi, and L. Donato. 1967. Patterns of serum albumin metabolism in renal diseases. In Physiology and Pathophysiology of Plasma Protein Metabolism. G. Bierke, R. Norberg, and L. O. Plantin, editors. Pergamon Press, London. 195-211.

5. Coles, G. A., D. K. Peters, and J. H. Jones. 1970. Albumin metabolism in chronic renal failure. Clin. Sci. (Oxf.). 39: 423-435.

6. Katz, J., G. Bonorris, and A. L. Sellers. 1963. Albumin metabolism in aminonucleoside nephrotic rats. J. Lab. Clin. Med. 62: 910-934.

7. Jensen, H., N. Rossing, S. B. Andersen, and S. Jarnum. 1967. Albumin metabolism in the nephrotic syndrome in adults. Clin. Sci. (Oxf.). 33: 445-457.

8. Kelley, V. C., M. R. Ziegler, D. Doeden, and I. McQuarrie. 1950. Labeled methionine as an indicator of protein formation in children with lipoid nephrosis. Proc. Soc. Exp. Biol. Med. 75: 153-155.

9. Blahd, W. H., M. Fields, and R. Goldman. 1955. The turnover rate of albumin in the nephrotic syndrome as determined by ${ }^{131}$ I-labeled albumin. J. Lab. Clin. Med. 46: 747-756.

10. Gitlin, D., C. A. Janeway, and L. E. Farr. 1956. Studies on metabolism of plasma proteins in the nephrotic syndrome. I. Albumin, $\gamma$-globulin and iron-binding globulin. J. Clin. Invest. 35: 44-56.

11. Freeman, T., and S. Cohen. 1961. Plasma protein metabolism in nephrotic syndrome. In Protides of the Biological Fluid. H. Peeters, editor. Proceedings of the 8th Colloquium, Bruges. Elsevier, Amsterdam. 230-234.

12. Jarnum, S. 1961. Fecal ${ }^{131}$ I-output after intravenous injection of ${ }^{131}$ I-labeled human serum albumin in normoand hypoproteinemic subjects. Scand.J. Clin. Lab. Invest. 13: 462-475.

13. Drabkin, D. L., and J. B. Marsh. 1955. Metabolic channeling in experimental nephrosis. I. Protein and carbohydrate metabolism. J. Biol. Chem. 212: 623-631.

14. Marsh, J. B., and D. L. Drabkin. 1958. Metabolic channeling in experimental nephrosis. IV. Net synthesis of plasma albumin by liver slices from normal and nephrotic rats. J. Biol. Chem. 230: 1073-1081.

15. Marsh, J. B., D. L. Drabkin, G. A. Braun, and J. S. Parks. 1966. Factors in the stimulation of protein synthesis by subcellular preparations from rat liver. J. Biol. Chem. 241: 4168-4174.

16. Katz, J., G. Bonorris, S. Okuyama, and A. L. Sellers. 1967. Albumin synthesis in perfused liver of normal and nephrotic rats. Am. J. Physiol. 212: 1255-1260.

17. McCormick, G. J., L. Shear, and K. G. Barry. 1966. Alteration of hepatic protein synthesis in acute uremia. Proc. Soc. Exp. Biol. Med. 122: 99-102.

18. Shear, L. 1969. Internal redistribution of tissue protein synthesis in uremia. J. Clin. Invest. 48: 1252-1257.

19. Mariani, G., R. Bianchi, A. Pilo, R. Palla, M. G. Toni, and L. Fusani. 1974. Albumin catabolism measurement by a double tracer technique in uraemic patients during a single dialytic treatment. Eur. J. Clin. Invest. 4: 435-442.

20. Blobel, G., and B. Dobberstein. 1975. Transfer of proteins across membranes. I. Presence of proteolytically processed and unprocessed nascent immunoglobulin light chains on membrane-bound ribosomes of murine myeloma. J. Cell Biol. 67: 835-851.

21. Bricker, N. S., S. Klahr, and R. E. Rieselbach. 1964. The functional adaptation of the diseased kidney. I. Glomerular filtration rate. J. Clin. Invest. 43: 19151921.

22. Lieber, C. S., D. P. Jones, J. Mendelson, and L. M. DeCarli. 1963. Fatty liver, hyperlipemia and hyperuricemia produced by prolonged alcohol consumption despite adequate dietary intake. Trans. Assoc. Am. Phys. (Phila.). 76: 289-301.

23. Shafritz, D. A. 1974. Protein synthesis with messenger ribonucleic acid fractions from membrane-bound and free liver polysomes. Translation characteristics of liver polysomal ribonucleic acids and evidence for albumin production in a messenger dependent reticulocyte cellfree system. J. Biol. Chem. 249: 81 \&R.

24. Shafritz, D. A., and W. F. Anderson. 1970. Isolation and partial characterization of reticulocyte factors $M_{1}$ and $\mathrm{M}_{2}$.J. Biol. Chem. 245: 5553-5559.

25. Crane, L. J., and D. L. Miller. 1975. A solid-phase radioimmunoassay for fibrinogen. Anal. Biochem. 64: 60-67. 
26. Palacios, R., R. D. Palmiter, and R. T. Schimke. 1972. Identification and isolation of ovalbumin-synthesizing polysomes. I. Specific binding of ${ }^{125} \mathrm{I}$-anti-ovalbumin to polysomes. J. Biol. Chem. 247: 2316-2321.

27. Kabat, E. A., and M. M. Mayer. 1967. Experimental Immunochemistry. Charles C. Thomas, Springfield, Ill. 22-96.

28. Lowry, O. H., N. J. Rosebrough, A. L. Farr, and R. J. Randall. 1951. Protein measurement with the Folin phenol reagent. J. Biol. Chem. 193: 265-275.

29. Fleck, A., J. Shepherd, and H. N. Munro. 1965. Protein synthesis in rat liver: influence of amino acids in diet on microsomes and polysomes. Science (Wash. D. C.). 150: 628-629.

30. Baliga, B. S., A. W. Pronczuk, and H. N. Munro. 1968. Regulation of polysome aggregation in a cell-free system through amino acid supply. J. Mol. Biol. 34: 199-218.

31. Sidransky, H., D. S. R. Sarma, M. Bongiorno, and E. Verney. 1968. Effect of dietary tryptophan on hepatic polyribosomes and protein synthesis in fasted mice. J. Biol. Chem. 243: 1123-1132.

32. Rothschild, M. A., M. Oratz, J. Mongelli, and S. S Schreiber. 1971. Alcohol-induced depression of albumin synthesis: reversal by tryptophan. J. Clin. Invest. 50: 1812-1818.

33. Rothschild, M. A., M. Oratz, and S. S. Schreiber. 1972. Effects of carbon tetrachloride on albumin synthesis. J. Clin. Invest. 51: 2310-2314.

34. Rothschild, M. A., M. Oratz, J. Mongelli, L. Fishman, and S. S. Schreiber. 1969. Amino acid regulation of albumin synthesis. J. Nutr. 98: 395-403.

35. Kelman, L., S. J. Saunders, S. Wicht, L. Frith, A. Corrigall, R. E. Kirsch, and J. Terblanche. 1972. The effects of amino acids on albumin synthesis by the isolated perfused rat liver. Biochem. J. 129: 805-809.

36. Rothschild, M. A., M. Oratz, and S. S. Schreiber. 1974. Alcohol, amino acids, and albumin synthesis. Gastroenterology. 67: 1200-1213.

37. Majumdar, C., K. Tsukada, and I. Lieberman. 1967.
Liver protein synthesis after partial hepatectomy and acute stress. J. Biol. Chem. 242: 700-704.

38. Koj, A., and A. S. McFarlane. 1968. Effect of endotoxin on plasma albumin and fibrinogen synthesis rates in rabbits as measured by the $\left[{ }^{14} \mathrm{C}\right]$ carbonate method. Biochem. J. 108: 137-146.

39. Neuhaus, O. W., H. F. Balegno, and A. M. Chandler. 1966. Induction of plasma protein synthesis in response to trauma. Am. J. Physiol. 211: 151-156.

40. Bianchi, R., G. Mariani, and A. Pilo. 1970. Albumin synthesis measurement by means of an improved two tracer method in patients with chronic renal failure: effects of low protein diet. J. Nucl. Biol. Med. 14: 136-144.

41. Shafritz, D. A. 1974. Evidence for nontranslated messenger ribonucleic acid in membrane-bound and free polysomes of rabbit liver. J. Biol. Chem. 249: 89-93.

42. Milstein, C., G. G. Brownlee, T. M. Harrison, and M. B. Mathews. 1972. A possible precursor of immunoglobulin light chains. Nat. New Biol. 239: 117-120.

43. Kemper, B., J. F. Habener, R. C. Mulligan, J. T. Potts, Jr., and A. Rich. 1974. Pre-proparathyroid hormone: a direct translation product of parathyroid messenger RNA. Proc. Natl. Acad. Sci. U. S. A. 71: 3731-3735.

44. Blobel, G., and B. Dobberstein. 1975. Transfer of proteins across membranes. II. Reconstitution of functional rough microsomes from heterologous components. J. Cell Biol. 67: 852-862.

45. Redman, C. M., D. Banerjee, K. Howell, and G. E. Palade. 1975. Colchicine inhibition of plasma protein release from rat hepatocytes. J. Cell Biol. 66: 42-59.

46. Dorling, P. R., P. S. Quinn, and J. D. Judah. 1975. Evidence for the coupling of biosynthesis and secretion of serum albumin in the rat. the effect of colchicine on albumin production. Biochem. J. 152: 341-348.

47. Baraona, E., M. A. Leo, S. A. Borowsky, and C. S Lieber. 1975. Hepatic accumulation of export proteins after chronic ethanol consumption. Gastroenterology. 69: 806. (Abstr.) 